\title{
Primordial Patterns of Security and Social Control System in Ilogbo Ekiti, Nigeria
}

\author{
Johnson Olusegun Ajayi \\ Department of Sociology, Ekiti State University, Faculty of the Social Sciences, Ado-Ekiti, Nigeria
}

Email address:

delight_top ayahoo.com

\section{To cite this article:}

Johnson Olusegun Ajayi. Primordial Patterns of Security and Social Control System in Ilogbo Ekiti, Nigeria. Humanities and Social Sciences. Vol. 6, No. 3, 2018, pp. 88-96. doi: 10.11648/j.hss.20180603.11

Received: December 10, 2016; Accepted: November 1, 2017; Published: July 10, 2018

\begin{abstract}
No matter how small a community is, ancient or modern, there is bound to be a system of keeping the community secure from external aggression or internal crises. Since peace and advancement can only be guaranteed in a safe environment, this is why the need arises to keep the community secure. The study examines the primordial pattern of security maintenance and the social control system in Ilogbo-Ekiti, with a view to seeing how some of the old pattern of keeping the community save could be integrated into the modern pattern for more efficient and effective protection of human community. The paper hinged the study on social control and labelling theories while secondary data were collected through Focus Group Discussion (FGD) and Key Informant Interview (KII). The paper concludes that some of the primordial patterns of crime control can be highly effective in keeping the environment safe and secure if properly harnessed and re-engineered.
\end{abstract}

Keywords: Community, Security, Primordial, Safety, Social Control

\section{Introduction}

Security is as important as human existence, unless the life and property of man are secure there cannot be any appreciable advancement in human society, human lives are regulated by rules that are sometimes consciously obeyed and sometimes unconsciously adhered to. In a small undifferentiated society where interaction is closely knitted the role of the adult male is roughly the same with some differences only among those who are married, single, or widowed. The only important economic differentiation is between men and women. The Aoro alone performs a distinct religious role; and except for the chiefs, with limited authority and older men who exercise an unofficial and informal leadership, there is no formal structure of political roles. Families and other-informal-primary groups make up the important units within the society as a whole.

Social roles are inclusive rather than segmental in IlogboEkiti, As a result of communal relationship the interaction is long lasting, inclusive and intimate or personal. They take on intrinsic significance rather than being instrumental. The reciprocal expectation of persons involved in these primary relationships are diffuse and generalized; one must live up to standards of respect, loyalty, affection, or love for example rather than merely fulfill specifically, defined responsibilities. There is therefore no complexities in the apprehension of offenders, no matter the notoriety of the miscreant the Egbe Awere comes handy in dealing with such knotty and high level atypical and aberrant behavior.

There are various kinds of organizations based on age, sex, and marital status, though these are likely to be small primary groups rather than special interest associations. Structurally therefore among the Ilogbo Ekiti people we have the agba ilu the assembly of the elders of the community who sit with the Kabiyesi in council. With the paramount ruler of the village also are his chiefs who assist in the day to day running and administration. Thus the social, economic and political spheres are regulated informally through the chiefs who are closer to the people. Top among the chiefs are the Ejemu, the Odofin, Enurin and the Eisikin. Problems and difficulties are tabled in the palace, solutions are the prerogatives of the paramount ruler and his chiefs in council. The women are held together under the Eye loori she settles quarrels and every marital and intractable family problems that have to do with women. The people are held together by that strong social bond of 'we-feeling'.

Like MacIver and Page (1949) have pointed out: life in Ilogbo-Ekiti is never complex as small number of persons 
meet "face to face" for companionship, mutual aid, the discussion of some questions that concern them all, or the discovery and execution of some common policy. The strength of the community lies in the strong social interconnections. The community is homogeneous with strong sense of group solidarity, tradition permeates all aspects of life and the range of alternative patterns of behavior open to individuals is inevitably restricted. Peace and security are therefore the concern of all and sundry.

This study is an investigation into the effectiveness and relevance of the primordial patterns of security maintenance and social control system in Ilogbo Ekiti, Nigeria since it is becoming obvious that the formal system of security maintenance in the country is constantly fraught with lots of challenges, chances are that an integration of this system with the formal structure might help a great deal in curbing the excesses of criminals in the modern society.

\section{Literature}

\subsection{Deviance and Social Control in Pre-Colonial Nigeria}

Onoge, in his work, social conflicts and crime control in colonial Nigeria in 1993, wrote brilliantly on this topic, he expressed his views on how societies in precolonial time kept their community safe and secure from crime and criminals through sentries and other traditional powers and forces. Quoting Blyden 1908 cited by Lynch (ed.) 1971 he argued that the tribes have laws regulating every function of human life and laws are known to all the members of the tribe, and justice is administered by the tribal chiefs in the presence of the whole people in the village or town, where any violation of tribal law may have taken place. There is no need for standing armies. The whole people of the villages or town are jointly and severally guidance and preservers of the peace.

Onoge also argued that the volume and types of orderthreatening conflicts, crime and deviance in any society are virtually related to the character of the society's social structure and value orientation. This was clearly he stressed, the case with the social control practices of pre-colonial Nigerian communities. The practices were necessarily influenced by the structure of the societies and the values of the people. The pre-colonial societies share a number of features, certain common attitudes and values in their social relations regardless of societal type whether politically centralized or acephalous. A number of these similarities were reflected in many of their indigenous social control practices (Onoge, 1993).

The smallness of these communities within which social life was lived in the pre-colonial time meant that their members tended to know each other very well therefore making the social distance between them very narrow and thin. Hence gossip and ridicule were always available to bring pressure for conformity on the erring members of the community. The 'we' feeling was potent among members of a community, the acceptable standards of behavior were clear and well known to everyone. Therefore, individuals were never confronted by multiple standards and obedience to customary rules was easily reinforced and enforced (Milner, 1972). In as much as the importance of the forces of gossip, ridicule and public opinion which are spontaneous attributes of small homogenous communities like we have in IlogboEkiti is never in doubt, they were never sufficient safeguards for the maintenance of la $\mathrm{w}$ and order. Self-help as was elucidated by Onoge was also a recognized method of dealing with offences.

A thief or a sex offender may be beaten-up instantaneously by the victim (the husband of a woman who caught his wife read handed having sex with another man) who also may solicit the help of others in the community to inflict permanent injury on the offender. It was also possible for the victim to put magun a charm that may make the adulterer get glued to the woman or that may make him summersault several times before he dies. In another sense, self-help, was always subject to abuse hence societies always made provisions for regulated and structural social involvement. Consequently, the pre-colonial Nigeria societies also relied on a number of other secular, transcendental and celestial agencies to monitor social behavior and provide sanctions against criminal and aberrant behavior. There are some traditionally identified groups characteristically used in the detection, resolution and punishment of deviants and deviance. They are: The domestic extended family, the linage, age grade, women societies, title societies, ancestral cults, spiritual cults, divination and ordeals, secret societies, folklores, ridicule ceremonies, masquerade festivals and satirical song-fests.

Tamuno (1993) in his work crime and security in precolonial Nigeria also corroborated the ideas of Onoge (1993) earlier highlighted in the previous paragraph. He was of the view that the pre-colonial Nigerian communities were administered, kept secure and peaceful by the informal systems in use in the various communities (large or small) met the basic needs of crime- prevention, detection and punishment. He claimed that the people involved realized that crimes did not pay, besides, neither the high nor the mighty in the society could claim exemption from the sanctions in force in pre-colonial times. It was further stressed that in these settings, a high level of public security and public safety existed within each well-defined groups. Tamuno argued that in pre-colonial Nigeria there were traditional police who were mainly concerned with delivering 'messages' which occasionally had the force of summonses from local authorities, guarding the persons of rulers, acting as bailiffs and hangmen, the detection and arrest of criminals and generally assisting the elders of towns and villages in the maintenance of law and order.

Village and town heads messengers sometimes performed police functions for example summoning people before the traditional authorities to answer criminal and other charges. The close link between the duties of messengers and police persisted according to Tamuno, up till 1930s and 1940s when questions of reorganization of the local police force in the former Northern and Western Nigeria were seriously 
considered by the appropriate authorities. The sanctions of the informal social controls among rural populations, where the good conduct or deviant behavior of the component families could hardly have been kept secret, at times, rendered less urgent the existence of large scale police forces, prisons and mental hospitals which are the characteristics of the urban environment.

In the ancient Nigeria both human and supernatural agencies were supposed to have been actively involved, especially, in the prevention and detection of crime. The mystical link between dead and living forces, both in the making and enforcement of pre-colonial Nigeria standards of behavior is of crucial importance. The fear of breaking such laws and customs, involving dread punishment by unseen and alleged powerful elements in traditional religion, provided an effective preventive factor (Tamuno, 1993).

\subsection{Security Maintenance and Social Control}

Before we discuss the Ilogbo-Ekiti understanding, practice and experience of security and social control system, it is important to know how the two variables in this study are related; hence we will sociologically appraise them in other to bring to fore the nexus between the duos. First let's look at security maintenance, what does it mean, how is it practiced and how is it accomplished in society? Security maintenance is simply the art of keeping the society safe and secure by those who are charged with that responsibility informally or formally. It is the protection of individuals and communities from war and other forms of violence (Human Security Centre, 2005a). Though there are many other threats to people's life apart from systematic violence, like we have freedom from fear and want; poverty and poor governance.

Peaceful co-existence and security have been some of the major struggles of man for ages. Hence, the fabrication of weapons as well as construction of shelter and fence to ward off wild animals and keep enemies at bay. No society can attain and maintain any reasonable level of socio-economic progress without security to lives and property of the people. No wonder, Maslow identified security as the third priority of man in the hierarchy of needs. Threats to lives and property are from many corners such as can be even overwhelming for all the security agencies put together. The remarkable dimension noticeable is that the Nigerian government through Nigeria Police, had been trying to put the intelligent minds of its erudite officers toward tackling the multiform security challenges of the country. The police and all other security agencies can hardly go wrong in going the whole length of demonstrably applying the intelligence and community partnership approach toward guaranteeing security to a larger proportion of the population.

No genuine development can be expected in a society devoid of peace and security, Nigeria has been faced with serious security challenges right from the coming in of the democratically elected government of 1999. It was as if democracy is synonymous with violence in Nigeria. There was noticeable increase in armed robbery, kidnapping, rape, arson and other forms of deviant behaviors. The worst of all, the police who are statutorily charged with the responsibility of providing security to lives and property of the citizenry, seem to be incapable of arresting the venomous situation. The persistence of this scenario brought about community self-help inform of vigilante groups patronized by the public even the government.

\subsection{Ilogbo-Ekiti and Social Control System}

Theoretically, the social control paradigm assumes that human beings are neither good nor bad, but that man is born with the capacity to do wrong. Given that humans naturally try to gratify themselves with no concern for right and wrong, and that the wrong way may offer the quickest and most efficient way of achieving that gratification, it is conformity rather than deviance that must be explained. All societies have developed ways of making people conform, and the control theory is concerned with the processes that bind people to the social order (Linden, 2016).

The earliest social control theories explained how some types of social structure led to high rates of crime and deviance. Communities characterized by poverty, physical deterioration and racial or ethnic conflict were too disorganized to exert effective control over the behavior of residents. This early social disorganization theorists included Emile Durkheim, Shaw and McKay and Thrasher. In his monograph Suicide (1951), Durkheim pointed out the importance of social bonds just like Travis Hrischi (1969). It is believed that egoistic suicide results from a situation in which a person's social ties are so weak that he or she is freed from social constraints and acts only on the basis of private interests.

What can be gleaned from these theoretical perspectives to explain deviance and crime in Ilogbo-Ekiti community is poverty, just like Merton (1968) explained that when opportunities are differentially distributed in society those who have no means of obtaining the societal prescribed goals will ultimately cut corners to obtain the desired end. Those of them that engage in conventional crimes in the community may have done so as a result of lack which they have no control over. It is however believed that strong attachment to and belief in the values of the community might serve as safety valve to deviance. The people also belief that oruko rere san ju wura oun fadaka lo a good name is better than silver and gold. They also believe that a little with contentment is far much rewarding than a house full of riches but with problems. These beliefs constrain the individuals from act that may jeopardize the "we" feeling that make the community a whole.

\subsection{Security Maintenance}

There are various organizations in Ilogbo-Ekiti community, based on age, sex, or marital status, even though these are small primary groups rather than special interest associations. Thus we have different age grades the young move up to adulthood by going through test of strength mostly organized in the moonlight around the center of the 
community known as Upona Akobo under a leafy tree. The age grades there start from omoloroto who are the youngest they meet and eulogize themselves by a continuous chant of the name of their set thus:

omoloroto moin,

omoloroto moin

omoloroto moin,

omoloroto moin.

They engage in some physical show of strength by wrestling, the weak are thrown on the ground and others make gest of such fellow as unfit to be part of their set. The next set is called ekunle, one of them too also will chant the name of their group aloud and others will chorus it thus:

a ekunle,

a ekunle

a ekunle.

a ekunle

In the same manner the eldest group among the three age sets is known as egbo, in the same way they chant loudly their group thus:

a egbo moin,

a egbo moin,

a egbo moin

a egbo moin.

Then the physical show of strength through wrestling starts, sometimes the duel may be violent depending on the strength of the challengers.

Interestingly the teenagers move through these three age sets and graduate into a higher age grade of adulthood through arranged initiation which are quite elaborate, frenzied and festive in nature. The security of the community is mainly handled by the age grade called Egbe Awere. This age grade apprehend offenders and hand them over to the village chief in council for adjudication. They keep the society secure and maintain peace all year round. A chant of the name Egbe awere a mudi dooo portends serious problem, instantaneously the group gathers at a specified place in the community and without much ado, no matter the enormity or how herculean the problem is the group is up to the task in terms of readiness, efficacy and strength both physically and magically. Hence they are respected, adored and feared by all in Ilogbo-Ekiti community for the quick response to distress calls. There are other ways of dealing with knotty problems within Ilogbo-Ekiti community one of these ways is the Ipesi which is discussed in details below.

\subsubsection{The Ipesi}

The Ipesi is an acronym for a yearly festival usually organized by youths in the community, it comes up between August and September. All harms done in the community are recorded by the youths who sometime pretend as if they did not notice the goings-on in the community. Sometimes they clandestinely study the situation and note the house of the offender for action when Ipesi festival matures. Basically this festival is organized to ridicule and disgrace deviants and criminals within the society. The Ipesi drums are rolled out by youths and specialized drummers beat the drums to the admirations of all. The youths then danced round the community singing in derision of the known offenders. Their names are mentioned loudly and what they have stolen or the evil they have done to the community. Youths yell and scorn the offenders without limit. The houses of the offenders are blocked with firewood they could gather in the vicinity, water is then poured inside and at the entrance of the offender's house with great uproar and derisive singing. Among some of the deviants acts noted in a particular year were: A woman, who went into the market place to steal dried meat called tinko in local language, a notable man in the community who for God knows what, went into another's farm and stole some tubers of yam and another important person in the community who engaged in a devious act. At Ipesi festival the youths sang against the deviants in the community particularly the one that stole tinko and the other that stole ogbangba yam tubers, among the songs chanted then was:

Koi se ise o

Asoju Ipadi,

udi ran dudi ololole

Asoju ipadi,

ogbangba yun mo lerun o

Most of these offenders were so disgraced to the point that they found it so difficult to show their faces in the community, sometimes they took refuge in another distant village. A man felt so bad that he had no other option than to commit suicide, he shut himself instead of remaining to face the ridicule. These, in other words, were the community ways of reacting against and attenuating acts in violation of conduct norms or community standards.

\subsubsection{Eruku}

History has it that there were three major groups in IlogboEkiti, namely Iro, Omodewa, and Orikiran. A member of the community must compulsorily belong to one of these three groups. These groups were carefully put in place for the maintenance of order and peace in the community. The Eruku is the leader of Iro group which is one of the three traditional governing groups in Ilogbo-Ekiti, the head of that group is the Odofin. Whenever a thief or an enemy of the community is arrested, he or she will be taken before the Eruku the Chief Justice for necessary adjudication and penalty.

\subsubsection{Elegbe}

The leaders and the deputies of the three major groups in Ilogbo-Ekiti are all members of the Elegbe, each of them also have many other followers. It was a great honor in the olden days to be appointed a member of Elegbe. They are servants to the community charged with various responsibilities out of which we have:

1. Kidnapping a woman for a man to marry whether the woman likes the man or not

2. Beating of the Egumo drum - the sound in the day of battle - when there is confusion, war or difficulty in the community to alert the people and to assemble them in readiness to act

3. Arrest thieves, refractory and erring members of the community 


\section{Burry the community's paramount ruler when he dies}

\subsubsection{Eye Loori}

The Eye Loori that is the women leader in the community sits in council with the community's chief and all problems that has to do with the female folks are handled by the women leader. The women hold her position sacred. They always run away from being taken to the Eye Loori who adjudicate on all cases that has to do with the women folks. A grievous offence may sometimes make the Eye Loori to put ashes round the leg of the offender, when a case gets to this level it portends a bad omen.

The Eye loori settles family cases and disagreements between women in the community, she is seen as an agent of peace and love for women and the entire community. She pleads for women unity, care of the family and children. Sacrifices are offered on behalf of women for fruitfulness, peace and safety when in labor. Libations are poured to appease the gods to avert disaster in the entire community.

\subsubsection{Ooloode-Night Guard}

The Egbe Awere misused their traditionally ascribed powers sometimes in the $60 \mathrm{~s}$, instead of protecting the live and properties of the citizens within the community, they turned the power against the people, livestock were brazenly stolen in the dead of the night unchallenged, because of the charms and incantations they chant, the inhabitants of the community became disturbed as their means of livelihood were stolen. The problem dragged on for months, until the surreptitious attitude drew the ire of the generality, which led to the invitation of the law enforcement agents to arrest the situation. At the sight of the law enforcement agents where they were hiding inside the bush some of the magically powerful members of the group were said to have disappeared in a sweep of whirlwind through some incantations "anghi mo yi" nobody holds the wind. The rest were arrested and paraded through the street while they carry on their heads the goats and other livestock they have stolen and roasted ready to be eaten or sold through the cronies inside the community. This scenario brought serious question on this age grade as they became disgraced, disbanded and incarcerated by the law enforcement agent.

At the end of the truculent scenario, the whole community standing on the failure of the trusted group Egbe Awere resolved into hiring ooloode night guard from a nearby community who they thought has the magical wand to detect criminals before they carry out their nefarious acts in the community. Any criminal caught by the ooloode was treated with magical force, either he or she was made to involuntarily confess to the crime or disarmed and begin to sweep the floor until people wake up. These and many more tactics were the ways the community kept their environment peaceful, safe and secure before the advent of the modern day criminal justice system.

\section{Theoretical Frame of Reference}

This study is hooked on two theoretical perspectives they are deterrence theory and control theory, a variant of Michael Gottfredson and Travis Hirschi (1990) called a general theory of crime. These two theories are found suitable for this study because, punishment is given to those who err in Ilogbo-Ekiti community to control offending, correct the offender and deter would be offenders in the community. In the same vein the general theory becomes plausible because it is believed that those who violate the conventional order have low self control thereby encountering situations or opportunities in which crime will produce immediate gratification with relatively low levels of risk.

\subsection{Deterrence Theory}

The central thesis of this theoretical paradigm maintains that punishment diminishes crime. Jeremy Bentham and Cesare Beccaria both of the classical school of criminology see crime as a negative function of the certainty, severity and celerity of punishment that is, as punitive responses to crime increase in these three context, it is expected that the frequency of crime will decline. In other words crime rates are influenced and controlled by the threat of criminal punishment. Siegel (2007) argued that if people fear being apprehended and punished they will not risk breaking the rules, he stressed further that an inverse relationship should then exist between crime rates and the severity, certainty and celerity of legal sanctions. For example if the punishment for armed robbery is increased and the efficiency and effectiveness of the criminal justice system are enriched, it stands to reason that crime should decrease, the factor of severity, certainty and celerity of sanction may also affect or influence each other. For an example if the crime of kidnapping in Nigeria is punished severely but few kidnappers are ever caught or punished, the severity of punishment for kidnapping will probably not deter people from the crime. But if the certainty of apprehension and conviction is increased by modern technology, more efficient police effort, or some other forms of improvement in criminal justice system, even minor punishment might deter potential criminal. Criminologists tend to assume that certainty of punishment seems to have greater effect than its severity.

In other words the fact that if a person commits a crime and is promptly apprehended, it might go a long way to deter criminals than the severity of the punishment attached to a given criminal act. No robber will attempt a dive into trouble when he knows he has few chances of escape. He takes the risk if he calculates that it will be difficult to detect his nefarious act. People will be deterred from crime if the know that they will be caught; what happens afterwards seems to have less impact (Nagin and Pogarsky, 2003). The three elements in deterrence calculus are functionally related, it will be futile to emphasize an element over the rest. For instance if the effectiveness of policing is enhanced at the expense of prompt dispensation of justice it might even lead to an increase in crime and delinquency. Deterrence theory, holds that a person's criminal activity will decline as a result of being caught and punished. The most important thing to us 
here is the net effect of enhancing sanctions. Just like the words of Brown et al (2010) so long as punishment responses inhibit more crime than they cause, they may represent a valuable addition to our crime prevention arsenal. Deterrence exponents conclude that low levels of deviance can be credited to threats of sanction.

The various forms of informal punishment in Ilogbo-Ekiti is first to shame and humiliate the offender. It is believed that fear of shame and embarrassment will translate into people's abhorrence of crime and deviance. Those who fear being rejected by the significant others are always reluctant to get involved in criminal activities (See Briscoe, 2004). These factors show themselves in two ways. First, personal shame over violating conventional order and second, the fear of public disgrace if the violation becomes known to the public. Those who are of the opinion that their involvement in deviant behavior will cause them to feel ashamed are less likely to commit theft, rape, fraud, murder, arson and other offenses than those who report they will not feel ashamed (Grasmick and Bursik, 1990).

In Ilogbo-Ekiti community, crime is generally seen as behavior of the never do well, it is hated and people avoid any one that has criminal tendencies. Children are taught songs at home particularly during moonlight play, to warn them of the danger of crime and to teach them to run away from crime and any other deviant acts. The song goes thus:

Kini ngo fole se laye ti mo wa

Kini ngo fole se laye ti mo wa

Kaka kin jale ma kuku s'eru

Kini ngo fole se laye ti mo wa

It means, 'why will I steal in life, instead of stealing I'1l rather be a slave, why will I steal in life'. They believe that dedication and hard work will take one to a prosperous end instead of stealing or seeking for unmerited gratifications. The effect of informal control seems substantial because of the cohesiveness of the community structure and the type of crime. Ilogbo - Ekiti is not a complex or differentiated society, rather it is a highly unified community, where everyone knows one another and crime cannot be hidden from public cognition. On the basis of the cohesiveness of the community, the threat of informal sanctions seems to have greater effect on the community members. It is not uncommon for some who cannot stand the shame and ridicule of stealing to run away from the community or to commit suicide.

In this case therefore, the fear of informal sanctions may have a greater crime reducing impact than the fear of formal legal punishment (Ross, 1986; Tittle, 1980). The reason being that social control is influenced by the way people see and think about negative reactions from interactive contacts. Formal sanctions may act as a supplement to the informal patterns. It therefore means that the combination of both formal and informal systems of social control may have greater effectiveness on the decision to commit crime than each pattern acting singly (see. Burkett \&Ward, 1993). Siegel stressed that there are other studies that have found out that people who are committed to conventional moral values or believe crime to be sinful are unlikely to violate standards of behavior. Parading and hauling abusive words on offenders round the street during the Ipesi festive period serves to shame the deviants. This invariably produces a moral climate that helped reduce incidence of crime in Ilogbo-Ekiti community (see Snortum. 1990).

\subsection{Social Control Theory}

Travis Hirschi becomes important in the field of social control or social bond theory. His work rests upon the assumption that "a person is free to commit delinquent acts because his ties to the conventional order have somehow been broken" (1969:3). He stressed that humans, like other animals, will violate rules if those rules have not been socially indoctrinated as part of a moral code:

We are all animals, and thus all naturally capable of committing criminal acts....The chicken stealing corn from his neighbor knows nothing of the moral law; he does not want to violate rules; he wants merely to eat corn....No motivation to deviance is required to explain his acts. So, too, no special motivation to crime within the human animal... [is] required to explain his criminal acts (Hirschi, 1969: 31).

The presence of normative consensus in any given social environment implies that when social bond becomes weakened or broken it becomes easy for actors to violate the social order. When there is deficient ties to the social order, deviant impulses that most or all people have are likely to be acted upon. The weaker the ties, the more the likelihood of deviance manifestations. According to Akers and Sellers (2009) there are four principal interrelated elements of the social bond identified by Hirschi which are: attachment, commitment, involvement, and beliefs, the stronger these elements are with parents, adults, schoolteachers, and peers, the more the individuals behavior will be controlled in direction of conformity. It is assumed that the weaker they are, the more likely it is for the individuals to breach conventions. Hirschi averred also that these four elements are highly intercorrelated; therefore the weakening of one element will probably be accompanied by the weakening of another.

\subsubsection{Attachment}

This refers to the degree to which the actor has affective ties to other persons, most especially those in his primary group. If an individual is sensitive to the feelings of others and close to those others, this attachment will constrain his or her behavior because that individual will not want to hurt or embarrass the people he or she likes. Those who are deficient of these ties will be inconsiderate of others people's feelings and therefore are free to deviate. Children who do not get along with their parents and the significant others are more likely to be free to deviate than those who are close to the significant others.

\subsubsection{Commitment}

Commitment refers to the degree to which individuals have built up an investment in conventionality or a stake in 
conformity that would be jeopardized or lost by engaging in law violation or other forms of deviance. "The idea, then, is that a person invests time, energy, himself in a certain line of activity like getting an education, building up a business, acquiring a reputation for virtue" (Hirschi, 1969: 20). If a person decides to engage in deviance, that person will be putting his or her investment at risk. For example a young girl aspiring to be married will do everything to run away from fornication or any act of deviance for fear of jeopardizing her chance of marriage. The cost of losing one's investment in conformity prevents one from norm violation. Commitment, therefore, refers to a more or less rational element in decision to deviate from conventional patterns.

\subsubsection{Involvement}

This is ones engrossment in conventional activities, such as studying, spending time with the family, and participation in extracurricular activities. The central idea is that if people are busy with conventional activities, they will not have time to engage in any act of deviance. For instance a student who at the same time engaged in evangelistic ministry will probably find it unwholesome to engage in cultism in school as with his peers who are not engaged.

\subsubsection{Belief}

The concept of belief in social bond theory is defined as the endorsement of general conventional values and norms, especially the belief that laws and society's rules are morally correct and should be obeyed. Apparently the less a person believes he should obey the rules, the more likely he is to violate them.

\section{Method}

Because of the nature of this study that has to do with looking at the unwritten history, folkways, mores and practices of Ilogbo-Ekiti community and their patterns of dealing with deviation of social norms and values, qualitative method was used for data collection. This include Focus Group Discussion (FGD) and Key Informant Interview (KII). Some books of history written by some of the indigenes of the community were consulted to gather additional information.

Despite the fact that Ilogbo-Ekiti is a homogeneous community, the people were delineated by their family groups. Twenty six of such were identified, they are:

Erunwa, Odoode, Eyigbo, Ogbonmuta, Umogun, UleOgbeyo, Ule-Ogbomo, Uponna-Akobo, Okuta-Edi, UgboEku, Iyedi, Ule-Abaoroefun, Ule-Orolua, Ule-Ogun, Okegbala, Ule-Agirigan, Ule-Abasha, Imiya, Ule-Abasolo, Temidure, Ule-Abalamoeku., Ule-Abasha, Ule Abanurin, 1 Ule-Abasi, Ule Abajisun and Odiolowo

The twenty six clans identified were again grouped into 6 clusters, each cluster was made up of four family groups. Fifteen adult male and female who have lived in the community for ten years or more were chosen for the FGD based on their readiness to participate in the discussion. One opinion leader was chosen from each of the six clusters for the key informant interview (KII). In all, 6 Focus Group Discussion (FGD) sessions were held while 6 Key Informant Interviews (KII) were conducted, the data gathered were subjected to content analysis and ethnographic summaries to deal with the substantives

\section{Data Presentation and Analysis}

The data generated from the six focus group discussions and the in-depth interviews are presented here. As it has been stated before, there was a seeming consensus discovered among the focus groups discussants about their view on deviance and how they were treated in Ilogbo-Ekiti community, this was also aptly corroborated by the in-depth interviews held in the community. This was the main reason why a few of them were highlighted here just to avoid repetition. Essentially, the discussants were of the view that no deviant can go undiscovered in the community and when they were discovered there were usually subjected to some sanctions which might range from ridicule, ostracism, excommunication and death depending on the enormity of the crime committed. Hear this from a focus group (FGD) discussant

I have my family name to protect I'd rather go hungry that to steal. The humiliation and disgrace that follow the act of stealing is too grave for whatever benefits that may temporarily accrue to the thief.

Female FGD/ Ilogbo-Ekiti/ Temidure/Adult 40 years and above

[April 27, 2016]

This view was also corroborated by a key Informant who was of the opinion that:

Stealing in the community dents the image of the thief because the community is close and people know themselves. Whatever anyone does wrong easily comes to the open. The name and the family name of the thief is held in derision.

Male KII/Erunwa/ Ilogbo-Ekiti

[April 28, 2016]

Yet another Key Informant was of the view that:

Those who stole or misbehave in the community were seen as sick and therefore need to be given just desert. The community has some ways of dealing with deviants in the community to deter the would be violators of the community standards.

Female KII/Odo-Ode/ Ilogbo-Ekiti

[April 28, 2016]

Also discussants in a FGD session at Imiya affirmedd that:

When the means of survival are differentially distributed and seems unattainable no matter how hard you labor in this community, some people might take to unapproved ways like stealing, kidnapping, corruption etc. to meet their needs. Can you blame them? Sometimes they may be smart and not caught, but the shame is grave if they were caught in action.

Male FGD/Imiya/ Ilogbo-Ekiti

[April 27, 2016]

A key informant at Iyedi was of the opinion that:

It is always easy to trace the hoodlums around because we 
know ourselves. Sometimes ago someone approached me with a wish to sell a mattress and some other household furniture, I began to wonder where such a fellow would get those stuff to sell, little did I know that the materials were stolen from the house of one of the community's elite. The guy and his cohort were promptly arrested by the community's security group and handed over to the council of elders and chiefs in council and subsequently to the police.

Male KII/Iyedi/ Ilogbo-Ekiti

[April 28, 2016

The key informant ideas and comments at Iyedi was reinforced by the focus group discussion held at Odiolowo Street in Ilogbo-Ekiti. The consensus was that:

The traditional ways of crime prevention and keeping the community safe and secure here in Ilogbo-Ekiti before the emergence of the western style of policing were very effective, the community is small and homogeneous, we know ourselves, any stranger in the community was easily identified and monitored. Therefore detection of crime and apprehension of criminals were certain, quick and sanctioned.

Male FGD/ Ilogbo-Ekiti/ Odiolowo/Adult 40 years and above

[April 27, 2016]

The traditional mode of keeping the community safe and secure was given a good recommendation by a focus group discussion held in Eyigbo Street in Ilogbo-Ekiti. Thus supporting the views held by the in-depth interviews and other focus group discussions conducted. Hear this from the group:

Ulogbo as the discussant called it is constantly safe from all those embarrassment of the city villains except when one elderly woman was kidnapped, such things do not occur in our midst without apprehension. The perpetrator was fished out in no time and the woman gained her freedom. The consensus in the group was that the norms and values of the community are held inviolable. People hold in awe the conventional orders. Breaking the rules is an irritant to most people in this community, hence our children are properly socialized.

Male FGD/ Ilogbo-Ekiti/ Eyigbo/Adult 40 years and above [April 27, 2016]

At Upona Akobo, Ona Ubawe and Okuta-Edi, Ule Osolo FGD sessions and the Key Informant Interviews conducted they all revisited the type of security system employed to protect people's lives and property in Ilogbo -Ekiti. References were made to the traditionally instituted arsenals of social control, these are the Egbe Awere, which is the age grade in charge of security, the Eye Loori, the traditional head of all the adult women in the community, the Elegbe, the community sentries, the Eruku the Chief Justice, the Oloode the community watchmen sometimes remunerated at the other time voluntary and the Ipesi festival done to ridicule and disgrace erring members of the community. It was the consensus among these groups that Ilogbo-Ekiti community was kept alive and secure from internal and external aggressions by these groups afore mentioned.

\section{Discussion}

As it was earlier mentioned in the methodology, twelve focus group discussion sessions were held this was supported by twelve key informant interviews. Three FGD and three KII were presented to avoid repetitive results. All the focus group discussions held and the key informants were of the same opinion, and their views were similar it will be sterile presenting all of them here.

It is lucidly seen from the results of the KII and FGD that the conduct of the people in the community studied conforms to certain standards, standards that are considered appropriate in the society in which the live. These standards and rules and expectations are what we may refer to here as norms. The conduct of the people runs along in grooves, it is channelized in specific ways in this community just the way we may have it across societies. The people hold the norms and values of their community close to their chest because without regard to the community norms, social life would be impossible and there would be no order so cherished by the discussants in the focus group and the Key informants.

Society itself is a kind of order, which is made possible by the presence of rules and regulations and these rules are the essence of social organization. There are some people within the ordered society that are defiantly aberrant, the behavior of these people must be controlled, and this is why there are sanctions by the community. Sanctions are the supporters of the societal rules, the punishments applied to those who do not conform and the rewards given to those who deviate. There are more or less subtle ways of expressing disapproval of actions that violate societal standards, one of the less subtle ways is ridicule, a powerful social sanction because no one likes to be considered ridiculous by those whose opinions he values. Ridicule which was the main purpose of the Ipesi festival has been also one of the weapons of controlling erring members of Ilogbo-Ekiti community. Ridicule was what has been called according to Bierstedt (1970) 'satiric sanction' found to be so effective in some societies or groups as the only negative sanction needed and the sanction that was above all others used to induce conformity to customs of the society.

\section{Conclusion and Suggestion}

Security is so sacrosanct to any human society, it is one of those inalienable rights of man. Ilogbo-Ekiti community is also not an exception. The people love to walk and work free without molestation of any kind. Development comes in droves to any community that is safe and secure. Even though the pattern of keeping the community safe is not formal, the people love it and submit themselves to community values.

Offenders are disgraced and abhorred through the demonstration of total dislike and hatred to behaviors that violate commonly accepted standards, because social relationships are basically primary in nature offenders are easily apprehended and sentenced in public. This pattern of 
handling erring individuals in the society reduces the rate of recidivism. Hence it is suggested that some of the traditional patterns of social control will be useful as supplement to the formal system, if subjected to scrutiny to make sure none of the systems violates human rights.

\section{References}

[1] Briscoe, Z. (2004). Raising the bar: Can increased statutory penalties deter drunk drivers? Accident Analysis and Prevention. No 36 Pp. 919-929.

[2] Brown, S. E.; Esbensen, F.; \& Geis, G. (2010). Criminology: Explaining crime and its contents $7^{\text {th }}$ Edition. New Jersey: Matthew Bender \& Company, Inc..

[3] Bunkett, S. \& Ward, D. (1993). A note on perceptual deterrence. Religiously based moral condemnation and social control. Criminology 31 Pp. 119-134.

[4] Conley, D. (2011). You may ask yourself: An introduction to thinking like a Sociologist 2nd Edition. New York: W. W. Norton \& Company Ltd.

[5] Durkheim, E. (1951). Suicide. Translated by George Simpson. New York: Free Press.

[6] Gottfredson, M. \& Hirschi, T. (2010). A general theory of crime In Brown, S. E.; Esbensen, F.; \& Geis, G. (2010). Criminology: Explaining crime and its contents $7^{\text {th }}$ Edition. New Jersey: Matthew Bender \& Company, Inc. Pp. 304-311.

[7] Grasmick, H \& Bursik, R. (1990). Conscience, significant others and rational choice extending the deterrence model. Law and Society Review 24 Pp. 837-861.

[8] Hirschi, T. (1969). Social bond theory. In Brown, E. B., Esbensen, F. \& Geis, G. (2010). Criminology: Explaining crime and its control 7th Edition. New Jersey: Matthew Bender \& Company, Inc. Pp. 300-311.
[9] Linden, R. (2016). Criminology: A Canadian perspective (eighth edition). Toronto: Nelson Education.

[10] MacIver, R. M. \& Page, C. H. (1949). Society: An introductory analysis. New York: Holt.

[11] Milner, A. (1972). The Nigerian penal system. London: Sweet and Maxwell.

[12] Nagin, D. \& Pogarsky, G. (2003). An experimental investigation of deterrence: Cheating, self-serving bias and impulsivity. Criminology Vol. 41 Pp 165-195.

[13] Onoge, O. F. (1993). Social conflict and crime control in colonial Nigeria. In Tamuno, T., Bashir, I. L., Alemika, E. E. O. \& Akano, A. O. (eds.) (1993). Policing Nigeria: Past and present and future. Lagos: Malthouse Pp.151-186.

[14] Pressn, R.K. (1968). Social theory and social Structure. New York: The Free Press.

[15] Ross, H. L. (1986). Implications of drinking and driving law studies for deterrence research In Critique and Explanation, Essay in Honor of Gwynne Nettler, eds. Timothy Hartnagel and Robert Silverman. New Brunswick, NJ: Transaction Books Pp. 159-171.

[16] Siegel, J. L. (2007). Criminology: theories, patterns, and typologies $9^{\text {th }}$ edition. United States: Thomson Wadsworth.

[17] Snortum, J. (1990). Drinking - driving compliance in Great Britain. The role of law as a threat and as a moral eye opener. Journal of Criminal Justice. No 18 Pp. 479-499.

[18] Tittle, C. (1990). Sanctions and social deviance. New York: Praeger.

[19] Tamuno, T. N. (1993). Crime and security in pre-colonial Nigeria. In Tamuno, T., Bashir, I. L., Alemika, E. E. O. \& Akano, A. O. (eds.) (1993). Policing Nigeria: Past and present and future. Lagos: Malthouse Pp.123-150. 